Il dibattito contemporaneo sull'ecologia è largamente influenzato dalle tesi dell'antropologo francese Philippe Descola, che nel suo capolavoro pubblicato nel 2005 "Par-delà nature et culture" descrive come diverse culture si rapportano a quello che l'Occidente chiama natura ${ }^{1}$. La natura, in questo quadro, è essa stessa un elemento culturale diversamente accessibile in funzione del modo in cui è pensata e descritta. Si tratta di un contributo importantissimo e non solo per l'antropologia europea. Tuttavia, una delle tesi di questo libro è particolarmente problematica: quella che porta Descola a riconoscere nella cultura occidentale un'attitudine "naturalista" cioè oggettivante rispetto al resto dei viventi non umani. La "natura" in Occidente sarebbe unificata e definita dalla sua stessa assenza di anima o di spirito, là dove altre culture riconoscono una forma di soggettività a tutto ciò che vive e proprio per questo sono costrette a pensare nella "natura" una pluralità "culturale" che l'Occidente non percepisce. L'aspetto problematico proprio alla tesi è l'idea che l'animismo, l'attitudine che riconosce l'esistenza di una mente o dell'autocoscienza anche al di fuori dell'umanità o di un numero ristretto di animali sarebbe cioè impossibile o minoritario nelle culture occidentali. A queste ipotesi, quella di una cultura occidentale priva di qualsiasi sensibilità animista, si era opposto in realtà già qualche anno prima della pubblicazione del capolavoro di Descola un altro grande antropologo europeo, Alfred Gell. Alla fine del secolo scorso Gell pubblicò un capolavoro dal titolo "Art and Agency. An Anthropological Theory", in cui descrisse le forme culturali attraverso cui, anche nella cultura occidentale diventa possibile l'attribuzione di agency ad artefatti e oggetti e quindi praticare una forma di animismo strutturale per le nostre società, anche se irriflesso e inconsapevole. Esiste

\title{
THE NEW ANIMISM
}

The contemporary debate on ecology is largely influenced by the theses of the French anthropologist Philippe Descola, who in his masterpiece published in 2005 "Par-delà nature et culture" describes how different cultures relate to what the West calls nature ${ }^{1}$. Nature, in this framework, is itself a cultural element differently accessible according to the way it is thought and described. This is a very important contribution and not only for European anthropology. However, one of the theses of this book is particularly problematic: the one that leads Descola to recognize in Western culture a "naturalist" attitude, that is, objectifying the rest of non-human living beings. In the West, "nature" would be unified and defined by its very absence of soul or spirit, whereas other cultures recognize a form of subjectivity in everything that lives and for this very reason are forced innanzitutto una forma molto comune di animismo domestico e quotidiano, grazie a cui attribuiamo personalità alle cose: è il caso dei bambini e del loro rapporto con bambole e peluches, ma anche degli adulti, ogni volta che si sorprendono a parlare a un auto o a un computer. Si tratta però di un'attitudine ironica e metastabile: in questo tipo di comportamenti, spesso l'attitudine dominante è quella del come se, del gioco, della finzione, che fa si che il soggetto umano che per esempio parla con degli oggetti o si pone dinanzi ad essi come se fosse davanti a un altro soggetto possa entrare e uscire regolarmente da questo tipo di postura. L'attribuzione di soggettività non è un atto che ci obbliga a qualche conseguenza e non ha continuità temporale. Eppure c'è un'altra forma di animismo, più profonda e più radicata, in cui il riconoscimento del carattere soggettivo degli oggetti non è né ironico né instabile: si tratta dell'arte. Nella società occidentale esiste una sfera in cui siamo tutti inconsapevolmente ma immancabilmente animisti: chiamiamo arte in effetti quello spazio culturale in cui ci relazioniamo a degli oggetti come se fossero soggetti. Basta pensare a quello che succede in un museo: un museo, in fondo è un magazzino pieno di vecchi oggetti per cui nutriamo una sorta di speciale venerazione. Ogni giorno, nel mondo "occidentale", milioni di persone entrano in questi enormi depositi e si imbattono in porzioni più o meno rifinite di tela di lino coperta da strati di pigmento, o in strutture di acciaio, marmo, legno: eppure, invece di vedervi solo forme geometriche di materia estesa (come presupporrebbe l'attitudine culturale che Descola chiama naturalismo) vi scorgono la presenza un soggetto o di un'anima, vi leggono opinioni, o una visione del mondo di qualcuno che è esistito centinaia o migliaia di anni prima. Quando abbiamo a che fare con un to think in "nature" a "cultural" plurality that the West does not perceive. The problematic aspect of this thesis is the idea that animism, the attitude that recognizes the existence of a mind or self-consciousness even outside of humanity or a small number of animals, would be impossible or a minority in Western cultures. To this hypothesis, the one that Western culture devoid of any animist sensibility, was actually already opposed a few years before the publication of Descola's masterpiece another great European anthropologist, Alfred Gell. At the end of the last century, Gell published a masterpiece entitled "Art and Agency. An Anthropological Theory"2, in which he described the cultural forms through which, even in Western culture, becomes possible to attribute agency to artifacts and objects and then practice a form of structural animism for our societies, even if irreflective and unconscious. First of all, there is a very common form of domestic and everyday animism, thanks to which we attribute personality to things: this is the case of children and their relationship with dolls and soft toys, but also of adults, every time they are surprised to talk to a car or a computer. It is, however, an ironic and metastable attitude: in this kind of behavior, often the dominant attitude is that of as if, of play, of fiction, which means that the human subject who, for example, talks to objects or places himself in front of them as if he were in front of another subject, can regularly enter and leave this kind of posture. The attribution of subjectivity is not an act that obliges us to some consequence and has no temporal continuity.

Yet there is another form of animism, deeper and more deeply rooted, in 
manufatto artistico (ma si potrebbe dire anche quando siamo di fronte a un libro o a una pagina scritta), accettiamo l'idea che esso contenga una intensità psicologica, emotiva, mentale che è presente indifferentemente dalla natura non-anatomica della materia in cui insiste. Di fronte agli oggetti artistici siamo cioè tutte e tutti animisti.

Non abbiamo bisogno nemmeno di entrare nei musei per esserlo. Lo siamo anche prima di aprire la porta di casa. Lantropologo britannico che ha fondato l'antropologia materiale, Daniel Miller, ha pubblicato qualche anno fa un libro molto bello sul modo in cui accumuliamo cose a casa, intitolato "The Comfort of Things"3. Ha preso in esame una trentina di appartamenti in una via di Londra e ha descritto i diversi modi in cui le persone usano gli oggetti per arredare casa. Miller considera che questa forma di scelte è una sorta di piccola cosmologia personale: decidere cosa tenere a casa e cosa buttare via non è solo una decisione estetica o economica, è una decisione cosmologica, perché implica il tentativo di ricostruire diversamente il mondo. E viceversa, tutto a casa sembra trasudare della personalità di chi la abita: le cose assumono lo stesso status dei soggetti. Le case sono da questo punto di vista spazi vernacolari di animismo: luoghi in cui la materia è sempre intrisa di anima e di soggettività. Casa è quello spazio in cui siamo abituati a rapportarci a tutto ciò che è oggettivo come se fosse la presenza di qualcosa di soggettivo ${ }^{4}$. Ancora una volta, siamo animisti, senza aver bisogno di esserne coscienti.

Arte, design o architettura sono, in questo senso immensi archivi e depositi di animismo collettivo che ci educano a vedere soggetti là dove chiunque vede solo degli oggetti, ci abituano a conferire agentività a qualsiasi porzione di materia, a rapportarci al mondo come se fosse popolato da anime diverse dalla

which the recognition of the subjective character of objects is neither ironic nor unstable: this is art. In Western society there is a sphere in which we are all unconsciously but invariably animists: we actually call art that cultural space in which we relate to objects as if they were subjects. It is enough to think of what happens in a museum: a museum, after all, is a warehouse full of old objects for which we have a sort of special veneration. Every day, in the "western" world, millions of people enter these enormous storerooms and come across more or less finished portions of linen cloth covered with layers of pigment, or structures of steel, marble, wood: yet, instead of seeing only geometric shapes of extended matter (as the cultural attitude that Descola calls naturalism would presuppose) they see the presence of a subject or a soul, they read opinions, or a vision nostra. Nello sguardo di questi tre saperi la materia si dota di una vita spirituale che è la stessa di quella che ci permette di essere coscienti, senzienti, autoriflessivi. È per questo che il problema ecologico deve essere trasformato in problema estetico. Una grande ecofemminista australiana vissuta nel secolo scorso, Val Plumwood, aveva identificato la ragione principale della crisi ecologica con l'assenza di animismo o di "panpsichismo" nella cultura occidentale: è perché siamo incapaci di riconoscere la soggettività di piante, animali e batteri che ci siamo macchiati di genocidi su scala planetaria ${ }^{5}$. La soluzione, secondo Plumvood, sarebbe quella di disperdere la creatività e l'agentività che la teologia ha attribuito solo a Dio e alla sua copia, la specie umana, a tutte ciò che abita la terra che permetta di considerare l'evoluzione stessa come «la prova dell'esistenza di una mente presente nella natura, dell'intelligenza che implicano l'elaborazione e la differenziazione delle specie». Si tratterebbe dunque di estendere alla natura, l'animismo suppletivo con cui arte, architettura e design ci impongono di rapportarci ai nostri stessi artefatti.

Eppure l'analisi di queste forme inconsapevoli di animismo o di panpsichismo "europeo" non finiscono qui. In questi casi si tratta infatti di posizioni che permettono di relazionarsi socialmente alla materia come se fosse dotata di agentività e di soggettività, senza costruire una vera e propria ontologia. Ma ci sono altri esempi, più radicali, in cui anche se in maniera inconsapevole, si è arrivati a una forma di animismo ontologico. Bruno Latour aveva suggerito qualche anno fa che anche la scienza è una immensa riserva di animismo inconscio. Applicando ai laboratori scientifici il metodo che l'etnografia del secolo scorso applicava alle società non-europee prive di scrittura, Latour si accorse che la scienza, proprio là dove continua of the world of someone who existed hundreds or thousands of years before. When we deal with an artistic artifact (but we could also say when we are in front of a book or a written page), we accept the idea that it contains a psychological, emotional, mental intensity that is present regardless of the nonanatomical nature of the material in which it insists. That is to say, in front of artistic objects we are all animists. We don't even need to go into museums to be one. We are animist even before we open our front door. The British anthropologist who founded material anthropology, Daniel Miller, published a very nice book a few years ago about the way we accumulate things at home, called "The Comfort of Things"' . He looked at some thirty apartments on one street in London and described the different ways people use objects to furnish their homes. Miller considers that this form of choices is a kind of small personal cosmology: deciding what to keep at home and what to throw away is not just an aesthetic or economic decision, it is a cosmological decision, because it involves trying to reconstruct the world differently. And vice versa, everything in the house seems to exude the personality of those who live there: things take on the same status as their subjects. From this point of view, houses are vernacular spaces of animism: places where matter is always imbued with soul and subjectivity. Home is that space in which we are used to relating to everything objective as if it were the presence of something subjective $e^{4}$. Once again, we are animists, without needing to be conscious of it.

Art, design and architecture are, in this sense, immense archives and repositories of collective animism that educate us to see subjects where anyone else sees only objects; they accustom us to confer agentivity on any portion of matter, to relate to the world as if it were populated by souls different from our own. In the gaze of these three forms of knowledge, matter is endowed with a spiritual life that is the same as that which allows us to be conscious, sentient and selfreflective. This is why the ecological problem must be transformed into an aesthetic problem. A great Australian eco-feminist who lived in the last century, Val Plumwood, had identified the main reason for the ecological crisis with the absence of animism or "panpsychism" in Western culture: it is because we are unable to recognize the subjectivity of plants, animals and bacteria that we are guilty of genocide on a planetary scale ${ }^{5}$. The solution, 
a ripetere che c'è una frattura ontologica fra soggetti e oggetti, non smette mai di trasgredire questa divisione. Gli scienziati non possono fare a meno di rapportarsi alle macchine e alla materia come se fossero dei soggetti: gli attribuiscono capacità di agire ma anche la capacità di parlare. Lo facciamo anche noi del resto, ogni volta che pensiamo che il termometro "ci dice" la nostra temperatura. Così, la grande rivoluzione di Pasteur fu più politica che puramente ontologica: si trattava più di riconoscere ai microbi una agentività politica che non di scoprire la loro mera esistenza. La scienza non cessa di costituire ontologicamente i suoi oggetti in soggetti, anche se afferma esattamente il contrario. Più generalmente, se la modernità europea afferma una divisione metafisica fondamentale (una costituzione nelle parole di Latour) tra i soggetti e gli oggetti, essa non cessa di confondere le due categorie e far vivere gli oggetti al modo dei soggetti. In un qualche modo siamo sempre stati animisti ${ }^{6}$. Bisognerebbe cioè smettere di legare l'attitudine animista a una cultura o a un'epoca specifica: si tratta di un'attitudine universale che è propria di qualsiasi vivente.

L'intuizione di Latour è però importante per un'altra ragione. Se la scienza fa sempre il contrario di quello che dice, se cioé, pur affermando che si rapporta a ciò che studia come a degli oggetti, li tratta in verità come se fossero soggetti, allora dobbiamo leggere qualsiasi documento scientifico come se si trattasse di un immane esercizio di etnografia del non-umano. Che si tratti di botanica o zoologia, di virologia o di elettronica, di informatica o di fisica, tutto quello che abbiamo raggruppato sotto la rubrica un po' claudicante di scienze naturali non è che un'indagine sul comportamento di soggetti che non condividono la nostra forma. Spesso, esattamente come gli antropologi

according to Plumvood, would be to disperse the creativity and agentivity, that theology has attributed only to God and his copy - the human species - to all the inhabitants of the earth, allowing to consider evolution itself as «the proof of the existence of a mind present in nature, of the intelligence that implies the elaboration and differentiation of species». It would therefore be a matter of extending to nature the supplementary animism with which art, architecture and design require ourselves to relate to our own artifacts.

Yet the analysis of these unconscious forms of animism or "european" panpsychism does not end here. In fact, in these cases we are dealing with positions that allow us to relate socially to matter as if it were endowed with agentivity and subjectivity, without constructing a real ontology. But

del secolo scorso, si è preteso di trarre delle regole universali, dal loro comportamento; eppure al di là delle conclusioni, dovremmo cogliere in questa letteratura solo un esercizio di falsetto in cui l'etnografia fa di tutto per non apparire tale, una sorta di ventriloquismo del non-umano per interposta persona. Ed è attraverso questo punto di osservazione che il mondo si anima: non serve penetrare ulteriormente la materia di questo mondo, non serve nemmeno aggiungere scoperte a quello che sappiamo, non serve, soprattutto, rinnegare in maniera inane una cultura per invocare in maniera semplicista la conversione ad un'altra cultura. Basta osservare diversamente i saperi che ci circondano e cogliere in essi la loro stessa realtà: i saperi che ci circondano diventeranno anch'essi depositi di animismo che ci permetteranno di riconoscere la presenza di soggetti là dove vedevamo solo degli oggetti.

\section{NOTE}

${ }^{1}$ Descola, P. (2005), Par-delà nature et culture, Gallimard, Paris, France.

${ }^{2}$ Gell, A. (1998), Art and Agency. An Anthropological Theory, Oxford University Press, Oxford, UK.

${ }^{3}$ Miller, D. (2009), The Comfort of Things, Polity Press, Cambridge, UK.

${ }^{4}$ Coccia, E. (2021), Filosofia della casa. Lo spazio domestico e la felicità, Einaudi, Torino, Italia

${ }^{5}$ Plumwood, V. (2002), "Nature in the Active Voice", Australian Humanities Review 46, Environmental Culture: The ecological crisis of reason, London and New York, Routledge, pp. 113-129.

${ }^{6}$ Latour, B. (1987), Science in Action: How to Follow Scientists and Engineers through Society, Harvard University Press, Massachusetts; Latour, B. (1991), Nous n'avons jamais été modernes. Essai d'anthropologie symétrique, La Découverte, Paris, France.

than purely ontological: it was more a question of recognizing the political agentiveness of microbes than of discovering their mere existence. Science does not cease to ontologically constitute its objects into subjects, even if it claims exactly the opposite. More generally, if European modernity affirms a fundamental metaphysical division (a constitution in Latour's words) between subjects and objects, it does not cease to confuse the two categories and make objects live in the manner of subjects. In some way we have always been animists ${ }^{6}$. That is, we should stop linking the animist attitude to a specific culture or era: it is a universal attitude that is proper to any living being.

Latour's insight is however important for another reason. If science always does the opposite of what it says, that is, if, while claiming to relate to what it studies as objects, it actually treats them as if they were subjects, then we must read any scientific paper as if it were a huge exercise in ethnography of the non-human. Whether it be botany or zoology, virology or electronics, computer science or physics, everything we have grouped under the somewhat claudicant rubric of natural science is nothing but an investigation of the behavior of subjects who do not share our form. Often, exactly like the anthropologists of the last century, we have pretended to derive universal rules from their behavior; yet beyond the conclusions, we should grasp in this literature only an exercise of falsetto in which ethnography does its best not to appear as such, but a sort of ventriloquism of the non-human by interposed person.

And it is through this point of observation that the world becomes animated: 


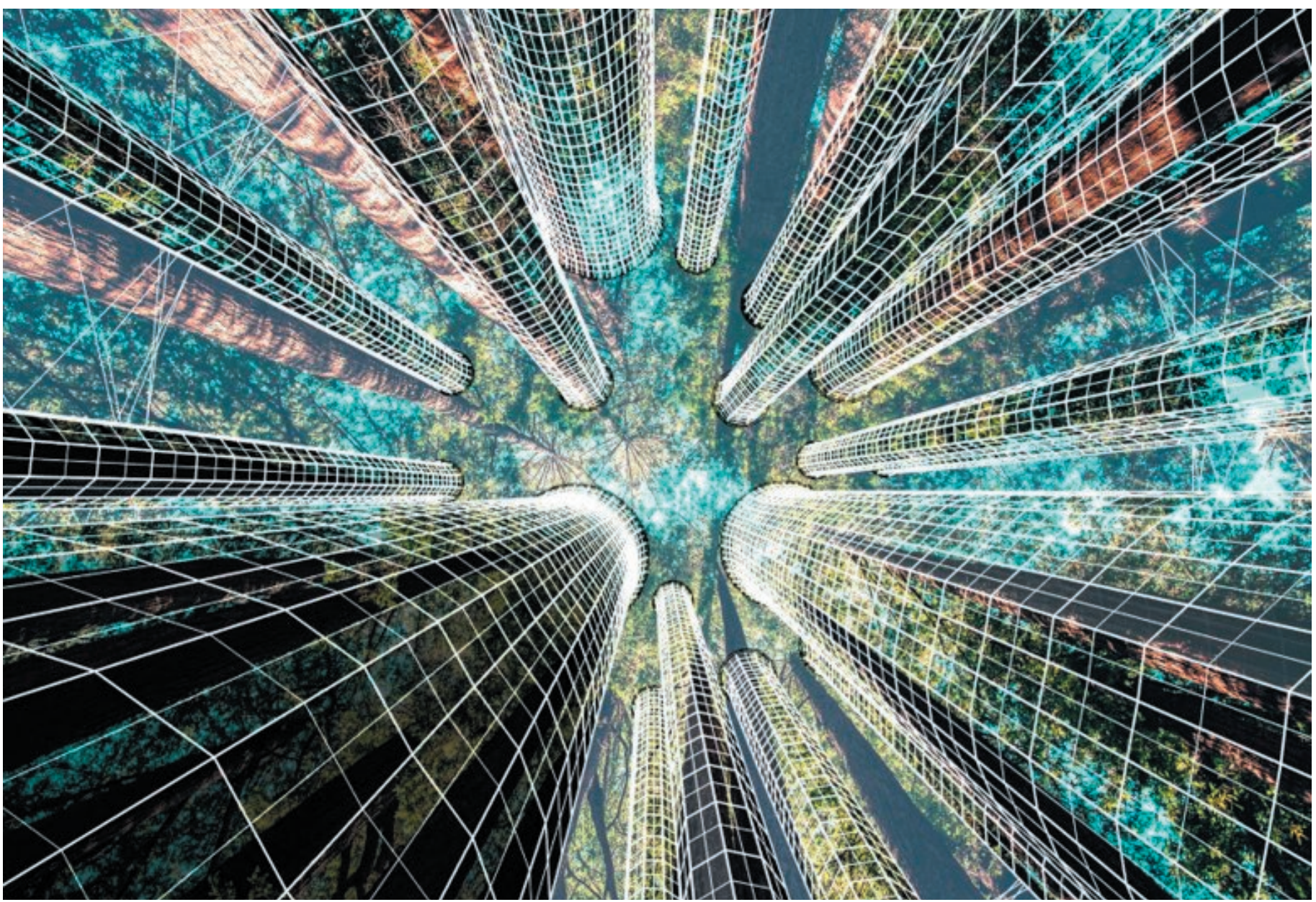

there is no need to penetrate further into the matter of this world, there is no need to add discoveries to what we know, there is no need, above all, to deny inanely a culture in order to invoke in a simplistic way the conversion to another culture. It is enough to observe differently the knowledge that surrounds us and grasp in them their own reality: the knowledge that surrounds us will also become deposits of animism that will allow us to recognize the presence of subjects where we used to see only objects.

\section{NOTES}

Descola, P. (2005), Par-delà nature et culture, Gallimard, Paris, France.

${ }^{2}$ Gell, A. (1998), Art and Agency. An Anthropological Theory, Oxford University Press, Oxford, UK.

${ }^{3}$ Miller, D. (2009), The Comfort of Things, Polity Press, Cambridge, UK.
${ }^{4}$ Coccia, E. (2021), Filosofia della casa. Lo spazio domestico e la felicità, Einaudi, Torino, Italia.

${ }^{5}$ Plumwood, V. (2002), "Nature in the Active Voice", Australian Humanities Review 46, Environmental Culture: The ecological crisis of reason, London and New York, Routledge, pp. 113-129. ${ }^{6}$ Latour, B. (1987), Science in Action: How to Follow Scientists and Engineers through Society, Harvard University Press, Massachusetts; Latour, B. (1991), Nous n'avons jamais été modernes. Essai d'anthropologie symétrique, La Découverte, Paris, France. 